\title{
REFLECTIONS ON PATCO'S LEGACY:
}

\section{LABOR'S STRATEGIC CHALLENGES PERSIST}

Richard W. Hurd

Professor of Labor Studies

Cornell University

340 ILR Research Building

Ithaca, NY 14853-3901

607-255-2765

rwh8@cornell.edu 
The 1981 strike by over 11,000 members of the Professional Air Traffic Controllers Organization (PATCO) stands out as a symbol of union decline. This dismal legacy is a product of President Ronald Reagan's harsh response to the job action, an ultimatum for controllers to return to work followed by wholesale permanent replacement of the strikers. Although PATCO's members were federal employees, their dismissal is typically portrayed as an invitation for all employers to emulate the President. The subsequent sharp drop in private sector strike activity has been traced (both rhetorically and statistically) to PATCO's demise, and even concessionary bargaining in industries far removed from the federal government and air transportation has been linked to this event.

Although the direct negative effect of PATCO has almost certainly been exaggerated, there is no doubt that the strike symbolizes the dramatic shift in labor's fortunes in the 1980s. In the first half of that decade private sector membership fell by three million, for a loss in union density of nearly one-third (Hirsch and Macpherson, 2006). The decline was caused by a myriad of factors - twin recessions in the early 1980 s, globalization, deregulation, a shift in the economy from manufacturing to services, and increased employer anti-unionism facilitated by the Reagan administration's conservative National Labor Relations Board. Also culpable were unions themselves as they clung to outmoded methods and stubbornly resisted change. PATCO's only link to this array of forces working against labor was the part it played in Ronald Reagan's offensive on the labor movement.

The penchant of journalists and academics to stigmatize PATCO by focusing exclusively on its role as fodder for the Reagan administration's anti-unionism detracts from important aspects of the unorthodox strategy of this fascinating labor organization. 
Although there were fatal tactical flaws in the PATCO game plan, this is one union that refused to be captive to past practices, instead developing creative approaches and pursuing an aggressive change agenda. A review of the organization's operations and priorities in the years leading up to the 1981 strike will facilitate an assessment of how PATCO's strategy compares to subsequent initiatives to transform U.S. unions.

\section{1: What Really Happened? ${ }^{1}$}

Nearly 80 percent of the nation's air traffic controllers walked off of the job on August 3, 1981 in an effort to achieve a shorter workweek and improved retirement benefits. The strike was precipitated by workplace stress and harsh management practices. Unfortunately for PATCO, the legitimate complaints of its members were lost in the furor surrounding the walkout, as the disruption in airline service and the illegality of a strike by federal employees overshadowed the actual bargaining objectives.

Momentum for the 1981 strike actually began to build in 1978 shortly after PATCO signed a three-year contract that disappointed many members. In response to pressure from rank-and-file activists, President John Leyden appointed the seven-member '1981 Committee' to begin preparation for the next round of bargaining. Although the committee was charged with designing a public relations campaign and developing a political/legislative agenda, its activist members reached the conclusion that, in spite of legal restrictions, the strike option offered the best potential source of bargaining leverage. Their preparations narrowed as they focused almost exclusively on internal mobilization in preparation for a possible strike. From the start the ' 81 Committee's members referred to themselves as 'choir boys,' and they were determined to design a 
program that would unify the geographically dispersed 15,000 air traffic controllers, primarily by recruiting other activists to join the choir.

The mobilization plan involved appointing one rank-and-file leader at each of the nation's more than four hundred air traffic control centers to serve as choir boy for his or her facility. Smaller facilities (typically at regional airports) were grouped into "clusters" so that 75 separate units (in effect operating as PATCO's locals) were involved in preparations for 1981. As the internal mobilization structure took shape, the influence of the ' 81 Committee grew. The committee's members became frustrated with President Leyden who wanted to emphasize modest political solutions and limited bargaining objectives rater than strike preparation. In 1980 word spread through the choir boy network that Leyden was too cozy with his management counterpart at the Federal Aviation Administration (FAA), and as discontent grew a palace coup was staged by PATCO Vice President Robert Poli who successfully ousted Leyden and assumed the presidency. Clearly Poli's ascendancy would have been impossible without the support of the ' 81 Committee, and it was the choir boys who really controlled the union throughout his presidency.

With Leyden out of the way, PATCO's strategy changed directions. Strike preparation took center stage, with the choir boys actively involved in extensive grassroots mobilization. For each local, seven committees were formed, with assignments ranging from picketing to building family support. As the contract expiration date approached, the majority of air traffic controllers participated in one or more of the local committees. A tight internal cohesiveness emerged and became so powerful that momentum for a strike seemed to push other options aside. 
The committee structure in effect democratized PATCO. Attendance at local meetings increased dramatically and commitment to the union's bargaining objectives was nearly universal. Considering the geographic dispersion of the membership, the extent of mobilization and rank-and-file militance as the contract expiration date approached in 1981 was truly remarkable.

The union's effectiveness at building internal solidarity was clearly its most notable accomplishment. Other aspects of PATCO's strategy were not so ingenious. As a federal employees' union, the leadership of PATCO (including the ' 81 Committee) recognized the importance of an aggressive political/legislative program. Unfortunately the political strategy was curious and ill-advised. PATCO endorsed Ronald Reagan for President with no apparent consideration given to his conservative agenda and anti-union reputation. After his election victory Reagan 'repaid' the union for its support with the appointment of J. Lynn Helms as head of the FAA. Helms had served as president of Piper Aircraft where he had personally coordinated strong-minded union resistance campaigns. In spite of the Helms appointment, PATCO's leaders expected Reagan's intervention on their behalf if, as anticipated, negotiations failed to produce an acceptable contract in the summer of 2001.

On the legislative front, the union eschewed Leyden's cautious approach and drafted a proposal that would have dramatically improved controllers' terms of employment. The problem with the proposal was its extravagance; the bill introduced in the House by a congressional ally would have increased pay by one-third, reduced the work week from 40 hours to 32 hours, and provided for full retirement after twenty years. There was simply no chance that a relatively small group of federal employees would 
receive such special treatment, especially in the environment created by PATCO's high visibility strike preparation. It was the union's 'demands' codified in the proposed legislation that publicly defined PATCO's strike objectives. The union made no effective effort to counteract the greedy image that this assured. Two in-depth independent studies funded by the government that substantiated job stress and authoritarian management offered ample ammunition for a possible campaign to cultivate public support, but PATCO seemed oblivious to the potential value of such publicity.

PATCO also made two other strategic miscalculations. First, the union assumed that a strike would essentially shut down the commercial air transportation system. This failed to take into account the substantial over-capacity in the industry in the years following deregulation. It became clear after the strike that the airline industry actually welcomed a forced reduction in air traffic, allowing them to take inefficient aircraft out of service and cancel unprofitable routes. In fact, during the months preceding the strike, the FAA quietly coordinated with the Air Transport Association to design a strike operation plan that spread flights throughout the day, which reduced peaks in the level of air traffic. The resulting 25 percent reduction in flights could be handled by roughly half of the air traffic control workforce. The 4,000 controllers who eventually crossed picket lines were supplemented by management personnel, and in some instances by military air traffic specialists.

The other strategic error was PATCO's attempt to stage this historic strike on its own. The union operated in isolation from the rest of the labor movement, with little advance communication and no coordination with other unions. Even unions in the airline industry whose members were directly affected by the walkout were not 
consulted. PATCO's isolation, its misread of economic leverage, a greedy public image, and the ill-conceived political program virtually assured failure. The union's exceptional internal mobilization effort was not enough to counter the external pressures and the union was destroyed. Subsequently the remarkable choir boy system has received little recognition from either the labor movement or the academic labor relations community.

\section{Labor's Response to Crisis ${ }^{2}$}

If PATCO had been simply a small union of federal employees that invited destruction by staging an ill-advised strike, a retrospective might delve into the details of the union's bargaining and political strategies and suggest alternative courses of action that could have produced a more positive outcome. Because the mythical status of PATCO transcends federal sector labor relations, however, it seems more appropriate to consider the case in the broader context. How has the labor movement responded to its crisis over the past quarter century, and how does this measure up in light of PATCO's experience?

For the first half of the 1980s private sector unions were nearly paralyzed by the myriad of economic and regulatory changes that confronted them. Rather than pursuing new approaches in response to the altered environment, the tendency was to blame problems on the Reagan administration, on anti-union employers, and on other external forces (including PATCO), while doggedly sticking to established practices. In 1985 a shift in attitude began to take hold after the AFL-CIO Executive Council endorsed The Changing Situation of Workers and Their Unions (AFL-CIO, 1985). This report was prepared by a select committee of national union presidents who had engaged over a twoyear period in what was effectively a strategic planning exercise. 
The report's core recommendations addressed weaknesses mirroring those that were so visible during PATCO's historic confrontation-labor's poor public image, the lack of economic leverage, and the need for greater political influence. Also recommended was increased attention to organizing, both outside the union to recruit more members and inside the union to mobilize current members. For the next ten years AFL-CIO President Lane Kirkland and the federation's staff promoted the Changing Situation as a blueprint for labor's renewal.

A marketing campaign to enhance labor's image was initiated with the theme 'Union Yes,' but the modest effort had far less influence on labor's image than the reality of declining power. By the mid-1990s the labor movement was no longer thought of as a collection of greedy, power-hungry special interests as portrayed by Ronald Reagan. Instead, a 1994 AFL-CIO-funded survey confirmed that unions were generally viewed as anachronisms, or simply as 'dinosaurs.' As was the case with PATCO, it was not the image problem and poor public relations that haunted the labor movement, it was the inability to exercise leverage.

In an attempt to enhance economic power in an era when the ineffectiveness of strikes was abundantly clear, the Kirkland AFL-CIO and most major unions turned to corporate campaigns. In spite of the terminology, the essence of the relevant methodology is equally appropriate for both the private and public sectors. The basic framework approaches any union campaign systematically starting with a careful analysis of the strengths and weaknesses of both the employer and the union. Based on the analysis, the union identifies potential sources of external pressure on the employer that will increase the cost of resistance and make settlement more attractive. The best 
campaigns consider a broad range of options, including suppliers, consumers, regulatory agencies, public opinion, stockholders, etc. Although strikes and other job actions are always an option, any decision to strike is reached only after carefully weighing the consequences and the potential contribution to the broader campaign.

PATCO clearly would have benefited from the type of analysis that is central to the corporate campaign framework. Unfortunately, this approach was not yet well developed. When PATCO members decided to strike, they were emulating the state-ofthe-art source of union power. Ironically most important corporate campaigns in the 1980s and 1990s were implemented only after failed strikes. It is only over the last ten years that unions have integrated corporate research into the core of their operations.

The third key aspect of the Kirkland program was increased attention to political action, which included early endorsements of candidates, increased campaign contributions, and more effective coordination across unions. The hope for a political solution to labor's plight proved irresistible, and Ronald Reagan's actions assured that the Democratic Party was the beneficiary of the heightened attention. When Bill Clinton was elected President in 1990, many union officials were confident that their problems would soon be solved.

PATCO's endorsement of Ronald Reagan was clearly ill-advised, but the labor movement's perpetual quest for political influence with Democratic officials is only marginally more realistic. The plight of private sector unions is linked directly to deregulation and free trade, and these policies have been embraced equally by Democrats and Republicans. Although both Jimmy Carter in 1978 and Bill Clinton in 1994 promised labor law reform to promote union growth, neither delivered on the promise. 
The final set of recommendations in the Changing Situation addressed union organizing strategy. In order to promote external organizing the AFL-CIO established the Organizing Institute to recruit and train a new generation of union organizers. Although this was an important development in its own right, it is not directly relevant to the PATCO experience. An equally significant and more relevant federation initiative was the effort to promote internal mobilization. In 1988 the AFL-CIO conducted a oneday training on internal organizing that was beamed via satellite to locations across the country. A manual based on that conference, Numbers That Count (AFL-CIO, 1988), received wide distribution and stimulated intense debate that influenced union strategy for at least the next ten years.

It was Numbers That Count that first described the "organizing model of unionism" and contrasted it to the "serving model." Under the prevailing servicing model, unions were characterized as third-party insurance agents offering representation to members. By contrast, the organizing model suggested that internal mobilization, activism, and rank-and-file militance could breathe life into a union and construct a foundation for future growth. Especially in the late 1980s and early 1990s, the organizing model concept inspired unions to develop training programs and campaign manuals in support of initiatives to promote grassroots mobilization.

Under the leadership of the ' 81 Committee and its choir boy network, PATCO's activist members had rejected the servicing model nearly ten years before the organizing model had been so named. Comprehensive, systematic one-on-one outreach to every air traffic controller, even those in the smallest facilities, was the bedrock of the success of the choir boy system. Indeed, the framework and level of involvement cultivated by 
PATCO's internal mobilization effort could have served as a prime exhibit of how to put the organizing model into motion, had the union's defeat not so tainted the labor movement's institutional memory.

One of the key features of PATCO's weakness was not addressed by the AFL$\mathrm{CIO}$ in its reform program, isolation from other unions. The federation was reluctant to question the tradition of national union autonomy, assuring that for most strategic decisions individual unions continued to operate independently. In part because of the persistent strategic isolation perpetuated by union autonomy, PATCO's mistakes and ultimate defeat were repeated needlessly in a steady stream of high visibility confrontations in the 1980s and 1990s-Eastern Airlines, International Paper, Hormel, Caterpillar, Bridgestone-Firestone,...

\section{Struggles of the Twenty-First Century Labor Movement ${ }^{3}$}

After ten years it was clear that the AFL-CIO's attempts to implement the recommendations of The Changing Situation had been insufficient to stem the decline in union density. A challenge to Lane Kirkland's presidency was mounted, and in October 1995 John Sweeney was elected to lead the federation. Ironically, in spite of the fanfare surrounding the change in leadership, Sweeney's New Directions program proved not to be substantially different from Kirkland's. The new administration did develop a more effective press relations operation, and labor's image seemed to improve, especially in the first few years. On the political front, tactics were refined, attention to field operations was intensified, and funding was nearly doubled. However, the close ties to the Democratic Party remained, without any cogent challenge to the neoliberal package of free trade, deregulation, and privatization. Support for corporate campaigns was 
expanded and unions were encouraged to apply relevant procedures from the start of major bargaining and organizing contests rather than after other options failed to deliver. Modest steps were taken to question national union autonomy and promote some degree of strategic coordination, but those efforts were rebuffed by major affiliates.

The biggest shift under Sweeney was to elevate attention to external organizing. A new Organizing Department was established and funding for the Organizing Institute was increased sharply. The rhetorical support for organizing during the early Sweeney years was incessant, and national unions were cajoled to increase funding sharply.

Missing from the agenda was any commitment to the organizing model. There seemed to be growing conviction that attention to internal organizing detracted from the primary objective of recruiting new members. Some even argued that effective internal mobilization in isolation merely served to increase employer antagonism, and thus was premature without first achieving sufficient density to exercise leverage in the relevant market.

By 2005 it was clear that the Sweeney revolution had itself fizzled, and the labor movement fractured under the weight of the relentless slide in union density. Seven major unions left the AFL-CIO and established the Change to Win Federation (CTW) based on a simple analysis. The CTW unions argue that the organizing priority needs to be elevated to a true position of preeminence, and more resources must be shifted to the task, with servicing and political action de-emphasized to assure absolute commitment to membership growth. Like the Sweeney AFL-CIO, the CTW unions largely have eschewed the organizing model, viewing mobilization in a limited way as a tool that can achieve turnout for demonstrations in support of external recruitment campaigns. 
When assessing the potential for union revitalization twenty-five years after PATCO unwittingly ushered in an era of persistent union decline, it is this rejection of the organizing model that is most troubling. The key positive lesson of PATCO was the value of a comprehensive grassroots program to mobilize members around job-related concerns. Against all odds the choir boy network transformed PATCO from a small and inconsequential organization of technical workers employed by the federal government into a force that could not easily be brushed aside. An inspired, active rank and file committed to the union is insufficient to assure success, of course. Effective strategic leadership with perspective and a realistic plan to exercise economic and political leverage is also essential. Clearly it is the realm of union leadership and strategy where PATCO failed.

Revitalization of the labor movement will require strong, creative leadership, perhaps of the sort being exhibited by the more outspoken leaders of unions affiliated with the CTW. If twenty-five century unions hope to inspire the current generation of workers who do not enjoy the benefits of collective representation, they must demonstrate first that they are capable of inspiring their own members. It is difficult to imagine steady union growth if labor cannot project strength both from the top down and from the bottom up. Where unions develop an internal culture that embodies collective values and militant action, they will be establishing the foundation for potential growth. It is here at the grassroots where the legacy of PATCO will again come to life. 


\section{Notes}

${ }^{1}$ The information in this section is based on Hurd (1986) and Hurd and Kriesky (1986).

${ }^{2}$ The substantive information on AFL-CIO strategy in this section is based on Hurd (2002).

${ }^{3}$ For a more thorough review of the Sweeney AFL-CIO and the recent debate about union strategy and structure, see Hurd (2004). 


\section{References}

AFL-CIO. 1985. The Changing Situation of Workers and Their Unions. Washington, DC: AFL-CIO

AFL-CIO. 1988. Numbers That Count. Washington, DC: AFL-CIO

Hurd, Richard. 1986. "A Retrospective on the PATCO Strategy," in The Air Controllers Controversy: Lessons from the PATCO Strike, by Arthur Shostak and David Skocik, Human Sciences Press, 206-214.

Hurd, Richard and Jill Kreisky. 1986. "The Rise and Demise of PATCO

Reconstructed," Industrial and Labor Relations Review, v. XL, October, 115-122.

Hirsch, Barry T. and David A. Macpherson. 2006. Union Membership and Earnings Data Book, Bureau of National Affairs.

Hurd, Richard. 2002. "Contesting the Dinosaur Image: The U.S. Labour Movement's Search for a Future," Society in Transition, v. 33, no. 2, 227-240.

Hurd, Richard. 2004. "The Failure of Organizing, The New Unity Partnership and the Future of the Labor Movement, Working USA, v. 8, September, 5-25. 
